\title{
Effective Power of a Massey Ferguson MF 435 Tractor Engine Using Diesel and Loofah Biodiesel
}

\author{
Akande, F.B., Oniya, O.O. \& Ibiyemi O. \\ Department of Agricultural Engineering \\ Ladoke Akintola University of Technology \\ Ogbomoso, Nigeria \\ E-mail: toyinprayer@yahoo.com
}

\begin{abstract}
This study was aimed at determining the effective power of a Massey Ferguson MF 435 tractor engine using diesel and loofah biodiesel. The indicated parameters of the absolute pressure, absolute temperature and specific volume at the completion of the intake, compression, combustion and expansion process were determined for both fuel (diesel and biodiesel). The values gotten from the indicated parameters were used for the construction of the indicated diagram from which mean effective pressure and the indicated power were determined. The effective power of the tractor engine when powered with diesel and loofah biodiesel were determined to be $54.06 \mathrm{KW}$ and $54.04 \mathrm{KW}$ respectively, which falls within the category II tractor power rating classification $(30-70 \mathrm{~kW})$ general purpose tractor. The performance of a tractor diesel engine using loofah biodiesel compared favorably with automotive gas oil (diesel). Therefore, Loofah biodiesel has good potentials as an alternative fuel for diesel engines.
\end{abstract}

Keywords: Anaerobic digestion, Biogas, Energy recovery, Effluent, edstock.

Aims Research Journal Reference Format:

Akande, F.B., Oniya, O.O. \& Ibiyemi O. (2018): Effective Power of a Massey Ferguson MF 435 Tractor Engine Using Diesel and Loofah Biodiesel. Advances in Multidisciplinary \& Scientific Research Journal. Vol. 4. No.1, Pp 65-82

\section{INTRODUCTION}

Energy is an essential input for economic growth, social development, human welfare, agricultural development and improving the quality of life. Since their exploration, the fossil fuels continued to be the major conventional energy source. With increasing trend of modernization and industrialization, the world energy demand is also growing at faster rate. Apart from their indigenous production, majority of developing countries including Nigeria import petroleum products to cope up with the increasing demand for energy. Thus, a major chunk of their hard earned export earnings is spent on purchase of petroleum products (Kaul et al., 2005).

The awareness of energy and environmental problems encouraged many researchers to investigate the possibility of using alternative fuels instead of fossil fuel and its derivatives. Biodiesel, which is produced from different vegetable oils (soybean, rapeseed, sunflower and other oilfeeds), seems very good for several reasons. They can replace diesel oil in boilers and internal combustion engines without major adjustments, only a small decrease in performances is reported (Bhattacharyya and Reddy, 1994; Graboski and McCormick, 1998; Schumacher et al., 1992). Biodiesel is a viable alternative source of energy to automotive gas oil for diesel engines.

In spite of the renewability, biodegradability and minimal sulphur content of biodiesel, most researches encourage the use of biodiesel directly in compressed-ignition engine without any special or further modification of the engine (Barabás et al., 2010; Bamigboye and Oniya, 2012). Furthermore, fuel formulation on the other hand is a huge area that is not fully explored. The aim of this study is to evaluate the effective power of a Massey Ferguson MF 435 tractor engine when powered with diesel and loofah biodiesel fuel and to determine the absolute temperature, absolute pressure and specific volume at the intake, compression, combustion and expansion process 


\section{METHODOLOGY}

A Massey Ferguson MF 435 tractor diesel engine parameters served as a basis for the tractor biodiesel engine. The basic parameters of the selected tractor engine as provided by the manufacturer are as follows:

Prototype tractor: Massey Ferguson (MF 435)

Engine type: Perkin 4000

Effective power: $54 \mathrm{~kW}$

Rated Engine Speed: 2200rpm Compression ratio, $\varepsilon=16: 1$

Number and type of cylinder: $\mathrm{i}=4 \mathrm{p}$ Firing order: $1-3-4-2$

Stroke to bore ratio, $(\mathrm{S} / \mathrm{D}): 127 \mathrm{~mm} / 100 \mathrm{~mm}$

Injection sequence: 1-3-4-2

Maximum power at rpm: ISO14396 - cv: 72kW @ 2200rpm

Maximum torque at rpm: ISO14396- Nm: 267 @ 1400 rpm

(Source: Massey Ferguson owner's manual)

The following assumptions were made.

- The rated engine speed $=2200 \mathrm{rpm}$

- The stroke to bore ratio $=127 \mathrm{~mm} / 100 \mathrm{~mm}$

- Mechanical efficiency of the existing diesel engine $=86 \%$

\subsection{Parameters for the Construction of Indicated Curve.}

The parameters determined for the construction of indicated curve for tractor diesel engine fuelled with diesel and biodiesel. The absolute pressure $\mathrm{P}$, absolute temperature $\mathrm{T}$ and specific volume $\mathrm{V}$ were determined at points: $\mathrm{a}-$ completion of intake, $\mathrm{c}$ - completion of compression, $\mathrm{z}$ - completion of combustion and b - completion of expansion process.

\subsection{Determination of parameters at the completion of intake process.}

The pressure $\mathrm{P}_{\mathrm{a}}$ and temperature $\mathrm{T}_{\mathrm{a}}$ at completion of intake process and commencement of compression process was determined as follows for biodiesel according to Akande (2004) and Vivek (2012).

The pressure $\mathrm{P}_{\mathrm{a}}$ in MPa during the intake process for biodiesel was determined separately from equation (1)

$P_{a}=\frac{\eta_{v} P_{0}(\varepsilon-1) T_{a}+P_{r} T_{0}}{\varepsilon T_{0}} \quad 1$

$\eta_{v}$ biodiesel $=0.91$ Abayeh et al. $(2013)$

$\eta_{v}$ diesel $=0.85$ (Akande 2004)

$\varepsilon=$ compression ratio $=16: 1$

$\mathrm{P}_{\mathrm{o}}$ and $\mathrm{T}_{0}=$ atmospheric pressure and temperature

$\mathrm{P}_{\mathrm{o}}=1$ standard atmospheric pressure $=101.325 \mathrm{kPa}$

$\mathrm{T}_{0}=27^{\circ} \mathrm{C}=300 \mathrm{~K}$

$\mathrm{P}_{r}$ and $\mathrm{T}_{\mathrm{r}}=$ pressure and temperature as a results of residual gases in the cylinder

$\mathrm{P}_{\mathrm{r} \text { biodiesel }} 1.06 \mathrm{mPa}=1060 \mathrm{kPa}$ Akande (2004)

$\mathrm{T}_{\mathrm{r} \text { biodiesel }}=114^{\circ} \mathrm{C}=387 \mathrm{~K}$

Substituting the parameters

$$
\begin{aligned}
& P_{\text {a diesel }}=\frac{0.85 \times 101.325 \times(16-1) \times 300+(1060 \times 300)}{16 \times 200}=146.99 \mathrm{kPa} \\
& P_{\text {a biodiesel }}=\frac{091 \times 101.225 \times(16-1) \times 200+(1060 \times 200)}{16 \times 200}=152.69 \mathrm{kPa}
\end{aligned}
$$


The temperature $\mathrm{T}_{\mathrm{a}}$ in $\mathrm{K}$ during the intake process

$$
\begin{aligned}
& T_{a}=\frac{a P_{a} T_{o}}{\eta_{v}(z-1) P_{0}+\frac{T_{Q}}{T_{r}} P_{r}} \quad 2 \\
& \mathrm{~T}_{\text {a diesel }}=\frac{16 \times 146.48 \times 100}{0.85 \times(16-1) \times 101.325+\frac{3 \times 4}{397} \times 1060}=333.82 \mathrm{~K} \\
& \mathrm{~T}_{\text {a biodiesel }}=\frac{16 \times 152.69 \times 300}{0.91 \times(16-1) \times 101 \times 195+\frac{3100}{397} \times 1060}=332.42 \mathrm{~K}
\end{aligned}
$$

\subsection{Determination of parameters at the completion of compression process}

The pressure $\mathrm{P}_{\mathrm{c}}$ and temperature $\mathrm{T}_{\mathrm{c}}$ at the completion of compression process and commencement of combustion process was determined according to Akande (2004) and Vivek (2012).

The pressure $\mathrm{P}_{\mathrm{c}}$ in MPa during the compression process:

$P_{c}=P_{R} E^{n_{1}}$

Where $n_{1}$ is the polytropic index for compression, assume ranges from (1.0 to 1.40$) n_{1}=1.39$ Engineeringtoolbox (2012)

$\mathrm{P}_{\mathrm{c} \text { diesel }}=\quad 146.99 \times 16^{1.39}=6934.5 \mathrm{kPa}$
$\mathrm{P}_{\mathrm{c} \text { biodiesel }}=152.69 \times 16^{1.39}=\quad 7203.4 \mathrm{kPa}$

The temperature $\mathrm{T}_{\mathrm{c}}$ in $\mathrm{K}$ at the completion of compression process

$\begin{array}{ll}T_{c}=T_{a} z^{n_{1}-1} & 4 \\ \mathrm{~T}_{\mathrm{c} \text { diesel }}=333.82 \times 16^{(1.39-1)}= & 984.28 \mathrm{~K} \\ \mathrm{~T}_{\mathrm{c} \text { biodiesel }}=332.42 \times 16^{(1.39-1)}= & 980.15 \mathrm{~K}\end{array}$

The specific volume $V_{c}$ in $m^{2}$ at the completion of the compression process

$V_{c}=\frac{V_{a}}{\varepsilon}$

Where

$v_{a}=\frac{8.314 \times 10^{-2} T_{a}}{\mu_{a} P_{a}}$

6

$\mu_{a}=$ Molar mass of air $28.97 \mathrm{~g} / \mathrm{mol}$ (Molar mass, 2014)

$\mathrm{V}_{\text {a diesel }}=\frac{9.214 \times 10^{-3} \times 27292}{28.97 \times 146.99}=6.52 \times 10^{-4} \mathrm{~m}^{3}$

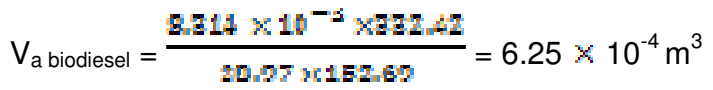

Therefore,

$\mathrm{V}_{\mathrm{c} \text { diesel }}=\frac{6 \mathrm{52} \times 10^{-4}}{16}=4.08 \times 10^{-5} \mathrm{~m}^{3}$

$\mathrm{V}_{\mathrm{c} \text { biodiesel }}=\frac{6 \mathrm{s5} \times 10^{-4}}{16}=3.91 \times 10^{-5} \mathrm{~m}^{3}$ 


\subsection{Determination of parameters at the completion of combustion process}

The pressure $\mathrm{P}_{z}$ and temperature $T_{z}$ at the completion of combustion process and commencement of expansion process was determined according to Adgidzi and Akande (2007).

$P_{z}=\lambda_{\mathrm{p}} \times P_{c}$

Where $\lambda_{p}=1.90=$ the level of increase in pressure at the end of combustion process.

Recall for diesel $\mathrm{P}_{\mathrm{c}}=6934.5 \mathrm{kPa}=6.935 \mathrm{MPa}$ and for biodiesel, $\mathrm{P}_{\mathrm{c}}=7203.4 \mathrm{kPa}=7.203 \mathrm{MPa}$

$P_{z \text { disul }}=1.90 \times 6.935=13.18 \mathrm{MPa}$

$P_{z \text { biodiessl }}=1.90 \times 7.203=13.69 \mathrm{MPa}$

The temperature $T_{z}$ is determined from combustion equation for a four stroke diesel engine.

$\left(\mu C_{v}+8.28 \lambda_{p}\right) T_{c}+\frac{\varepsilon H_{u}}{\omega L_{0}\left(1+\gamma_{r}\right)}=\mu \cdot \mu_{c p} \cdot T_{r[c \varepsilon)} \quad 8$

Where,

$\mathbf{E}=$ co-efficient of effective combustion of fuel

$\mathrm{E}_{\text {biodiesel }}=0.8$ (Biarnes, 2013)

$\mu C_{v}=$ mean molar heat capacity of air at constant volume in $\mathrm{kJ} / \mathrm{kmol} \mathrm{K}$

$\mu_{c p}=$ mean molar capacity of burnt gases under constant pressure $\mathrm{kJ} / \mathrm{kmol} \mathrm{K}$

$H_{u}=$ heat of combustion. $H_{u \text { dissel }}=42,500 \mathrm{~kJ} / \mathrm{kg}$ (Akande, 2004; Bamgboye and Oniya, 2012),

$H_{u \text { biodissal }}=28750 \mathrm{~kJ} / \mathrm{kg}$ (Bamgboye and Oniya, 2012; Oniya and Bamgboye 2012)

$\mu C_{v}=20.16+1.738 T_{c} \times 10^{-3} \quad g$

Recall for diesel $T_{C}=984.28 \mathrm{~K}$ and for biodiesel $T_{C}=980.15 \mathrm{~K}$,

$\mu C_{v \text { dissel }}=20.16+1.738 T_{c \text { dissel }} \times 10^{-3}$

$\mu C_{v}=20.16+1.738(984.28) \times 10^{-\frac{\pi}{3}}=21.88$

$\mu C_{v}=21.88$

$\mu_{c p}=8.28+\left(20.1+\frac{0.921}{\alpha}\right)+\left(\frac{13.82}{\alpha}+15.49\right) \times 10^{-4} T_{z(c \varepsilon) d i \varepsilon v \varepsilon I}$

Where $\alpha=$ excess air co-efficient (Assume $\alpha=1.9$ ) (Abbe et al., 2013)

$\mu_{i p}=8.28+\left(20.1+\frac{0.921}{1.9}\right)+\left(\frac{13.82}{1.9}+15.49\right) \times 10^{-4} T_{\text {z(n) }}$ Almat

$\mu_{s p}=28.86+22.76 \times 10^{-4} T_{z(n) \text { dins }} \quad 10$

Substituting the parameters for biodiesel into equation 3.18

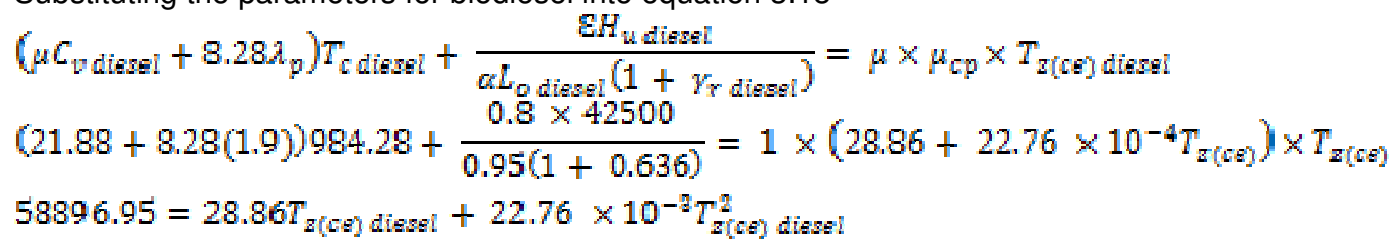

Re-arranging

$22.76 \times 10^{-3} T_{z(c \sigma) \text { diesel }}^{2}+28.86 T_{z(c e) \text { diss }}-58896.95=0$

$T_{z(c) \text { dinsal }}=\frac{-b \pm \sqrt{b^{2}-4 a c}}{2 a}$

$a=22.76 \times 10^{-3}, b=28.86, c=-58896.95$ 
$T_{\text {I(cs) dissl }}=\frac{-28.86 \pm \sqrt{28.86^{2}-4 \times 22.76 \times 10^{-3} \times-58896.95}}{2 \times 22.76 \times 10^{-1}}$

$T_{y(c e) \text { disgel }}=\frac{-28.86 \pm 78.71}{0.04552}$

$T_{z(c s) \text { dissl } 1}=1095.12 \mathrm{~K}$

$T_{z(c e) \text { ditsel } 2}=-2363.14 \mathrm{~K}$

Therefore,

$T_{z \text { cos dissel }}=1095.12 \mathrm{~K}$

Recall for biodiesel $T_{c}=980.15 \mathrm{~K}$,

$\mu C_{v \text { biodiasel }}=20.16+1.738 T_{\text {c biodisst }} \times 10^{-\frac{\pi}{7}}$

$\mu C_{v \text { biodisel }}=20.16+1.738(980.15) \times 10^{-3}=21.87$

$\mu C_{v \text { biodizal }}=21.87$

$\mu_{s p}=8.28+\left(20.1+\frac{0.921}{\alpha}\right)+\left(\frac{13.82}{\alpha}+15.49\right) \times 10^{-4} T_{z(c)}$

Where $\alpha=$ excess air co-efficient (Assume $\alpha=1.9$ ) Abbe et al. (2013)

$\mu_{c p}=8.28+\left(20.1+\frac{0.921}{1.9}\right)+\left(\frac{13.82}{1.9}+15.49\right) \times 10^{-4} T_{\square[c \varepsilon]}$

$\mu_{c p}=28.86+22.76 \times 10^{-4} T_{z(c \varepsilon)}$

Substituting the parameters for biodiesel into equation 3.18

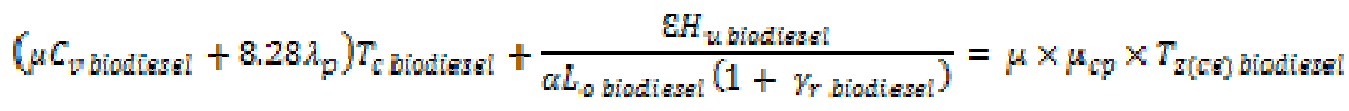

$$
\begin{aligned}
& (21.87+8.28(1.9)) 980.15+\frac{0.8 \times 28750}{0.819(1+0.594)}=1 \times\left(28.86+22.76 \times 10^{-4} T_{z}\right) \times T_{z(c 8)} \\
& 54473.56=28.86 T_{z(c s) \text { biodiesel }}+22.76 \times 10^{-3} T_{z(c s) \text { biodissel }}^{2}
\end{aligned}
$$

Re-arranging

$$
\begin{aligned}
& 22.76 \times 10^{-3} T_{z(c e) \text { biodiesel }}^{2}+28.86 T_{z(c e) \text { biodiesel }}-54473.56=0 \\
& T_{z(n) \text { bindinsl }}=\frac{-b \pm \sqrt{b^{2}-4 a c}}{2 a} \\
& a=22.76 \times 10^{-8}, b=28.86, c=-54473.56 \\
& T_{\text {zos }) \text { bindisel }}=\frac{-28.86 \pm \sqrt{28.86^{2}-4 \times 22.76 \times 10^{-7} \times-54473.56}}{2 \times 22.76 \times 10^{-7}} \\
& T_{\text {I(ces) biodiesel }}=\frac{-28.86 \pm 76.11}{0.04552} \\
& T_{z(c e) \text { biodisal } 1}=1,038,01 \mathrm{~K} \\
& T_{\text {z(ce) biodissel } 2}=-2,306.02 \mathrm{~K}
\end{aligned}
$$


Therefore,

$T_{z(c e) \text { biodiesel }}=1,038.02 \mathrm{~K}$

\subsection{Determination of parameters at the completion of expansion process}

The pressure $\mathrm{P}_{b}$ and temperature $T_{b}$ at the completion of expansion process and commencement of intake process was determined according to Akande (2004) and (Ajav) et al. (2000).

\section{PRE-EXPANSION INDEX}

The temperature $T_{z}$ for both diesel and biodiesel using pre-expansion index will be determined from equation 13 .

$p=\frac{\varepsilon T_{z}}{\lambda_{p} T_{c}}$

Where,

$T_{z}=\frac{\rho \times \lambda_{p} \times T_{c}}{\varepsilon}$

$\rho=1.06, \lambda_{p}=1.9, \varepsilon=0.80, T_{c \text { diassl }}=984.28 \mathrm{~K}, T_{c \text { biodiesel }}=980.15 \mathrm{~K}$

$\tau_{\text {zisel }}=\frac{1.06 \times 1.9 \times 984.28}{0.80}=2477.92 \mathrm{~K}$

$T_{z \text { biodiesel }}=\frac{1.06 \times 1.9 \times 980.15}{0.80}=2467.53 \mathrm{k}$

The $\mathrm{P}_{\mathrm{b}}$ for biodiesel was determined by the compression ratio of the pre-combustion index $\delta$.

$\delta=\frac{\varepsilon}{\rho}$

$\delta=\frac{16}{1.06}=15.09$

The pressure $\mathrm{P}_{\mathrm{b}}$ was determined as follow:

$P_{b}=\frac{P_{z}}{\delta^{n_{2}}}$

For diesel, $\mathrm{P}_{\mathrm{z}}=13.18 \mathrm{MPa}$, biodiesel, $\mathrm{P}_{\mathrm{z}}=13.86 \mathrm{MPa}, \delta=15.09, \mathrm{n}_{2}=1.24$

$P_{\text {b disnl }}=\frac{13.18}{15.09^{1.24}}=0.455 \mathrm{MPa}$

$P_{\text {biodiasel }}=\frac{13.69}{15.09^{1.24}}=0.473 \mathrm{MPa}$

The temperature $T_{b}$ was determined as follow:

$T_{b}=\frac{T_{x}}{g^{m_{2}-1}} \quad 16$ 
Where:

$\mathrm{n}_{2}=$ polytropic index of expansion

Recall $\mathrm{T}_{\mathrm{z} \text { diesel }}=2477.92 \mathrm{~K}, \mathrm{~T}_{\mathrm{z} \text { biodiesel }}=2467.53 \mathrm{~K}$

$T_{\text {bi dievel }}=\frac{2477.92}{15.09^{1.24-1}}=1291.18 \mathrm{~K}$

$T_{\text {b biodiesel }}=\frac{2467.53}{15.09^{1.24-1}}=1286.40 \mathrm{~K}$

Determining the Volume at Combustion and Expansion process according to Adgidzi and Akande (2007)

$V_{\text {a diesel }}=6.52 \times 10^{-4} \mathrm{~m}^{3}, \quad V_{\text {a biodiesel }}=6.25 \times 10^{-4} \mathrm{~m}^{3}$

$V_{c \text { diesel }}=4.08 \times 10^{-5} \mathrm{~m}^{3}, \quad V_{c \text { biodiesel }}=3.91 \times 10^{-5} \mathrm{~m}^{3}$

Volume at combustion process $\mathrm{V}_{\mathrm{z}}$ :

$V_{z}=\rho V_{c}$

Recall, $\mathrm{V}_{\mathrm{c} \text { diesel }}=4.08 \times 10^{-5}, \mathrm{~V}_{\mathrm{c} \text { biodiesel }}=3.91 \times 10^{-5}$

$V_{z \text { diesel }}=1.06 \times 4.08 \times 10^{-5}=4.32 \times 10^{-5} \mathrm{~m}^{2}$

$V_{z \text { biodigsel }}=1.06 \times 3.91 \times 10^{-5}=4.14 \times 10^{-5} \mathrm{~m}^{3}$

$\frac{V_{a}}{V_{x}}=\frac{V_{b}}{V_{x}} \rightarrow V_{a}=V_{b}$

18

$V_{a \text { diessl }}=V_{b \text { dissel }}=6.52 \times 10^{-4} \mathrm{~m}^{2}$

$V_{a \text { biodiezel }}=V_{b \text { biodiesal }}=6.25 \times 10^{-4} \mathrm{~m}^{2}$

\section{THE INDICATED DIAGRAM}

The various pressure points $\left(P_{x}\right)$ and the volumes $\left(V_{x}\right)$ were used for both polytropic compression and expansion curves. The volume axis, $V$ was divided into twenty equal part from the $V_{c}$ to $V_{a}$ at indicated intervals for the engine. The corresponding values of $P_{x}$ was obtained using equations 19 and 20 for polytropic compression and expansion respectively. From polytropic compression equation:

$P_{x_{1}}=P_{a}\left(\frac{V_{a}}{V_{x}}\right)^{n_{1}}$

For polytropic expansion equation:

$P_{x_{2}}=P_{b}\left(\frac{V_{b}}{V_{x}}\right)^{n_{2}}$

Where: $n_{1}=1.39$ and $n_{2}=1.24$

From indicated diagram Fig. 3, the mean indicated pressure was determined from the equation 21. (Adgidzi and

Akande, 2007)

$P_{i}^{1}=\frac{\mu F}{l} \quad, \mathrm{MPa}$

Where:

$\mu=$ Pressure scale $(1 \mathrm{~mm}=0.1 \mathrm{MPa})($ Appendix A)

$F=$ indicated diagram area, $\left(\mathrm{mm}^{2}\right)$

$\boldsymbol{I}=$ length of indicated diagram, $(\mathrm{mm})$ 
For diesel

$F_{\text {dissei }}=2184 \mathrm{~mm}^{2}$

$I_{\text {diasel }}=180 \mathrm{~mm}$

$P_{\text {idiesel }}^{1}=\frac{0.1 \times 2184}{180}=1.213 \mathrm{MPa}$

For Biodiesel

$F_{\text {biod iesel }}=2368 \mathrm{~mm}^{2}$

$l_{\text {biodinst }}=180 \mathrm{~mm}$

$P_{\text {ibiodiszel }}^{1}=\frac{0.1 \times 2368}{180}=1.316 \mathrm{MPa}$

The value of the mean theoretical pressure in MPa in analytical method was determined according to Adgidzi and Akande, (2007) as follows:

$P_{i}^{\text {cal }}=\frac{P_{C}}{z-1}\left[\lambda_{p}(\rho-1)+\frac{\lambda_{p} \rho}{n_{2}-1}\left(1-\frac{1}{\delta^{n_{2}-1}}\right)-\frac{1}{n_{1}-1}\left(1-\frac{1}{\varepsilon^{n-1}}\right)\right] \quad 22$

For diesel

$P_{c \text { disul }}=6.935 \mathrm{MPa}, \varepsilon=16, \lambda_{p}=1.90, \rho=1.06, n_{2}=1.24, \delta=15.09$

Piglossl $=\frac{6.935}{16-1}\left[1.90(1.06-1)+\frac{1.90 \times 1.06}{1.24-1}\left(1-\frac{1}{15.09^{1.24-1}}\right)-\frac{1}{1.39-1}\left(1-\frac{1}{16^{1.39-1}}\right)\right]$

Plalessl $=0.462(0.114+8.392(0.479)-2.564(0.661)$

Pfalessl $=1.127 \mathrm{MPa}$

For biodiesel

$P_{0 \text { biodiesel }}=7.203$ MPa, $\varepsilon=16, \lambda_{p}=1.90, \rho=1.06, n_{2}=1.24, \delta=15.09$

Plalodisel $=\frac{7.203}{16-1}\left[1.90(1.06-1)+\frac{1.90 \times 1.06}{1.24-1}\left(1-\frac{1}{15.09^{1.24-1}}\right)-\frac{1}{1.39-1}\left(1-\frac{1}{16^{1.39-1}}\right)\right]$

Plal dissel $=0.480(0.114+8.392(0.479)-2.564(0.661)$

Pral ibdiszel $=1.171 \mathrm{MPa}$

The accuracy of construction of indicated diagram was determined by the error co-efficient in equation 23.

$S_{\text {id }}=\frac{P_{i}^{\text {ral }}-P_{i}^{1}}{P_{i}^{\text {all }}} \times 100 \%$

For diesel

$\delta_{\text {id dissl }}=\frac{1.127-1.213}{1.127} \times 100 \%$

$\delta_{\text {id disstl }}=-7.63 \%$

For biodiesel

$\delta_{\text {id biodiarsl }}=\frac{1.171-1.316}{1.171} \times 100 \%$

$\delta_{\text {id biodias el }}=-12.4 \%$

The error coefficient $\delta_{i d}$ must not be higher than 3 or $4 \%$ (Adgidzi and Akande, 2007). 
The actual mean indicated pressure in MPa was determined according to Adgidzi and Akande, (2007) as follows:

$P_{i}=P_{i}^{1} Y$

Where:

$\gamma=$ coefficient of incomplete indicated diagram

$\gamma=0.93$ (Adgidzi and Akande, 2007)

$P_{\text {disul }}=1.213 \times 0.93=1.128 \mathrm{MPa}$

$P_{\text {biodiaral }}=1.316 \times 0.93=1.224 \mathrm{MPa}$

The mean effective pressure in MPa was determined according to Adgidzi (1988) and Akande (2004)

$P_{\varepsilon}=P_{i} \eta_{m}$

25

Where:

$\eta_{\mathrm{m}}=$ Mechanical Efficiency of the engine 0.86

$P_{\text {diesel }}=1.128 \times 0.86=0.970 \mathrm{MPa}$

$P_{\text {s biodiasel }}=1.224 \times 0.86=1.053 \mathrm{MPa}$

The rated effective power $\mathrm{N}$ in $\mathrm{kW}$ for the tractor engine was determined according to Sen et al. (2008) and Akande (2004) as follows:

$N=\frac{p_{\varepsilon} n V_{l}}{60 \tau}$

For diesel

$N_{\text {diesel }}=\frac{0.970 \times 10^{6} \times 2200 \times 3.04 \times 10^{-3}}{60 \times 2}$

$N_{\text {diassl }}=54.06 \mathrm{~kW}$

For biodiesel

$N_{\text {biodiasel }}=\frac{p_{\text {e biadiasel }} n V_{l \text { biodinal }}}{60 \mathrm{~T}}$

$N_{\text {diesel }}=\frac{1.053 \times 10^{6} \times 2200 \times 2.80 \times 10^{-3}}{60 \times 2}$

$N_{\text {disst }}=54.04 \mathrm{~kW}$

\section{RESULTS AND DISCUSSION}

\subsection{Indicated Parameters}

The summary of results of the indicated parameters such as the absolute pressure, absolute temperature and specific volume at the completion of intake, compression, combustion and expansion processed of a Massey Ferguson MF 435 tractor engine when powered with diesel and loofah biodiesel are presented in Tables 1, 2 and 3.

\subsection{Parameters at the completion of intake process}

The absolute pressure at the completion of the intake process for both diesel and biodiesel were $0.147 \mathrm{MPa}$ and $0.153 \mathrm{MPa}$, respectively as shown in Table 1 . The difference between the absolute pressures at the completion of the intake process was as a result of the difference in the filling co-efficient of the cylinder with mixture, $\eta_{v}$ of the fuels in the engine. The absolute temperature at the completion of the intake process for both diesel and biodiesel were $333.82 \mathrm{~K}$ and $332.42 \mathrm{~K}$, respectively as shown in Table 2 . The difference is as a result of the effect of the residual gas temperature of $0.604 \mathrm{kmol} / \mathrm{kg}$ and $0.486 \mathrm{kmol} / \mathrm{kg}$ for diesel and biodiesel, respectively. This showed that the temperature was at the lowest at the completion of the intake process. 
The specific volume at the completion of the intake process for both diesel and biodiesel engine were $6.52 \times 10^{-4} \mathrm{~m}^{3}$ and $6.25 \times 10^{-4} \mathrm{~m}^{3}$, respectively as shown in Table 3. Tables 3 and 1 at the completion of intake process showed an increase in volume and decrease in pressure respectively for both diesel and biodiesel. The temperature was at the lowest at the completion of intake process as shown in Table 4.1b.

\subsection{Parameters at the completion of compression process}

The absolute pressure at the completion of the compression process for both diesel and biodiesel was determined to be 6.935 MPa and 7.203 MPa, respectively. This showed an increase in absolute pressure at the completion of the process for both diesel and biodiesel as shown in Table 1. According to Pulkrabek (1997), the absolute pressure at the end of compression ranges from 4.0 MPa to $7.5 \mathrm{MPa}$. The result showed that the absolute pressure falls within the acceptable limit at the end of compression process. The absolute temperature at the completion of the compression process for both diesel and biodiesel were $984.28 \mathrm{~K}$ and $980.15 \mathbb{K}$, respectively as shown in Table 2 . According to Pulkrabek (1997), the temperature at the end of compression ranges from $900 \mathrm{~K}$ to $1200 \mathrm{~K}$. The result showed that the temperature falls within the acceptable temperatures at the end of compression process.

The absolute volume for both fuel (diesel and biodiesel) at the completion of the compression process was $4.08 \times 10^{-}$ ${ }^{5} \mathrm{~m}^{3}$ and $3.91 \times 10^{-5} \mathrm{~m}^{3}$, respectively as shown in Table 3 . The result of absolute pressure and specific volume at the completion of compression for both fuels showed an increase in pressure with reduction in the volume when compared with the result at the completion of intake process. Also, the quantity of mixture in the cylinder at the completion of compression process for both diesel and biodiesel was $1.554 \mathrm{kmal} / \mathrm{kg}$ and $1.305 \mathrm{kmol} / \mathrm{kg}$, respectively.

\subsection{Parameters at the completion of combustion process}

The absolute pressure at the completion of the combustion process for both diesel and biodiesel was $13.18 \mathrm{MPa}$ and 13.69 $\mathrm{MPa}$, respectively as shown in Table 1. The increase in pressure was as a result of the work done (heat energy) released in the combustion chamber from the combustion of the fuel (diesel and biodiesel). The pressure reached the highest point at the completion of combustion process. The absolute temperature at the completion of the compression process for both diesel and biodiesel were $2477.92 \mathrm{~K}$ and $2467.53 \mathrm{~K}$. respectively as shown in Table 2. This showed that the highest temperature was reached at the end of combustion process. The increase in temperature was due to the combustion of fuel thereby releasing more heat energy in to the combustion chamber. The difference in their temperature was due to the difference in the heat of combustion of both fuel (diesel and biodiesel). The heat of combustion for diesel $K_{u \text { dissel }} w a s 42,500 \mathrm{~kJ} / \mathrm{kg}$ (Akande, 2004; Bamgboye and Oniya,

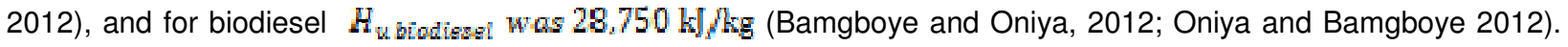
The specific volume at the completion of the combustion process for both diesel and biodiesel were $4.32 \times 10^{-5} \mathrm{~m}^{2}$ and $4.14 \times 10^{-5} \mathrm{~m}^{2}$, respectively as shown in Table 3 .

\subsection{Parameters at the completion of expansion process}

The absolute pressure and the specific volume at the completion of the expansion process for both diesel and biodiesel were $0.455 \mathrm{MPa}$ and $0.473 \mathrm{MPa}$ and $6.52 \times 10^{-5} \mathrm{~m}^{2}$ and $6.25 \times 10^{-5} \mathrm{~m}^{3}$, respectively as shown in Tables 1 and 3. At the end of expansion process the outlet valve will be open for the release of burnt gases in the cylinder which will definitely cause a drop in absolute pressure in the cylinder and an increase in the specific volume. The absolute temperature at the completion of the expansion process for both diesel and biodiesel was $1291.18 \mathrm{~K}$ and $1286.40 \mathrm{~K}$, respectively as shown in Table. 2. There was a drop in the temperature at the completion of the process compared to the completion of combustion process. According to Stone (1994) the absolute pressure and absolute temperature at the end of expansion ranges from $0.4 \mathrm{MPa}$ to $0.6 \mathrm{MPa}$ and $1100 \mathrm{~K}$ to $1300 \mathrm{~K}$, respectively. The results showed that the pressure and temperature falls within the acceptable limit at the end of expansion process. 


\subsection{Indicated Diagram}

The indicated parameters (absolute pressure and specific volume) gotten for both diesel and biodiesel fuels were used in the construction of the indicated diagram (diesel and biodiesel cycle) for Massey Fergusson MF 435 tractor diesel engine. The volume from $V_{c}$ to $V_{a}$ was divided into nineteen equal parts. The corresponding values of $P_{x_{1}}$ and $\boldsymbol{P}_{x_{2}}$ were obtained for both diesel and biodiesel as shown in Table A1 and Table A2 in Appendix, respectively.

The indicated diagrams for both fuel (diesel and biodiesel) were drawn from Table A1 and Table A2 in the Appendix, respectively as shown in Figures 1 and 2, respectively. The accuracy of construction of indicated diagram for diesel and biodiesel cycle were $-7.63 \%$ and $-12.4 \%$, respectively. The error coefficient result falls between the approved and acceptable limit of less than or equal to 3 or $4 \%$ (Adgidzi and Akande, 2007). The mean indicated pressure values for diesel and biodiesel were 1.213 $\mathrm{MPa}$ and $1.316 \mathrm{MPa}$, respectively. The effective power of the Massey Fergusson MF 435 diesel engine when powered with both fuel (diesel and biodiesel) was determined to be $54.06 \mathrm{~kW}$ and $54.04 \mathrm{~kW}$ respectively at the engine speed of $2200 \mathrm{rpm}$, which falls within the category II tractor power rating classification $(30-70 \mathrm{~kW})$ general purpose tractor.

\section{CONCLUSION}

The indicated parameters at the completion of each processes showed that biodiesel has higher pressure than diesel at the end of each processes while diesel has higher temperature and volume than biodiesel at the end of each processes (intake, compression, combustion and expansion). The performance of a tractor diesel engine using loofah biodiesel compared favourably with automotive gas oil (Diesel). Loofah biodiesel has good potentials as an alternative fuel for diesel engines. Therefore, performance of a tractor diesel engine using loofah biodiesel compared favourably with automotive gas oil. Therefore, Loofah biodiesel has good potentials as an alternative fuel for diesel engines. 


\section{REFERENCES}

1. Abayeh I.H, Garba I.H, Adamu H.M and Abayeh O.J (2013). Quality Characteristics of Luffa aegyptiaca seed oil; International Journal of Scientific and Engineering Research, Vol. 4, Issue 4

2. Abbe, N.V.C, Nzengwa R.,Danwe R., Ayissi Z.M, Obounou M (2013). Simulation of a DI Diesel Engine Performance Fuelled on Biodiesel Using a Semi-Empirical OD Model; Energy and Power Engineering, 2013, 5, 596-603

3. Adgidzi, D. (1988). Improvement of the Operational Indices of Tractors using Turbo-super charging. Unpublished M. Sc. Thesis submitted to the Department of Tractors and Automobiles, Agro-Technical University, Minsk, Minsk.

4. Adgidzi and Akande (2007). Theoretical Determination of the Effective Power of a Tractor Engine using Compressed Natural Gas as Alternative Fuel; Journal of Agricultural Engineering and Technology (JAET). Volume 15, pg 4-11

5. Akande F.B (2004). Comparison of Theoretically Determined Operational Characteristics of Existing (Diesel) and Compressed Natural Gas (CNG) Tractor Engine. Unpublished MEng thesis submitted to Department of Agricultural Engineering, FUT Minna, Nigeria

6. Ajav E.A, Singh B, Bhattacharya T.K (2000). Thermal balance of a single cylinder diesel engine operating on alternative fuels. Energy Conversion \& Management $411533 \pm 1541$

7. Bamgboye, I. A. and Oniya O.O. (2012). Fuel properties of loofah (luffa cylindrica L.) biofuel blended with diesel. African Journal of Environmental Science and Technology. Vol. 6(9), pp. 346-352.

8. Barabás, I., Todorut, A. and Baldean, D. (2010). Performance and emission characteristics of a $\mathrm{Cl}$ engine fueled with diesel-biodiesel-bioethanol blends. Fuel, Vol.89, No.12, (December, 2010) pp. 3827-3832

9. Bhattacharyya, S and Reddy, C.S (1994). Vegetable oils as fuels for internal combustion engines:a review. Journal of Agriculture Engineering Resources; 57:157-66.

10. Biarnes M, Freed, B and Esteves, J (2013) Combustion E Instruments International LLC http://www.EInst.com

11. Engineeringtoolbox, (2012) Resources, Tools and Basic Information for Engineering and Design of Technical Applications "Compression and Expansion of Gases", http://www.engineeringtoolbox.com/compression-expansion-gases-d 605.html accessed 23/10/2014.

12. Graboski MS and McCormick RL (1998). Combustion of Fat and Vegetable Oil Derived Fuels in Diesel Engines. Progressin Energy and Combustion Science; 24(2):125-64.

13. Kaul S, Kumar A, Bhatnagar AK, Goyal HB and Gupta AK (2005). Biodiesel: a clean fuel and sustainable fuel for future. Scientific strategies for production of non-edible vegetable oils for use as biofuels. All India seminar on national policy on non-edible oils as biofuels. SUTRA, IISc Bangalore.

14. Molar mass. (2014). In Wikipedia, The Free Encyclopedia. Retrieved 09:17, October 23, 2014, from http://en. wikipedia.org/w/index.php?title=Molar mass\&oldid=630081525

15. Oniya O.O and Bamgboye A.I (2012) Loofah (luffa cylindrica, I.) biodiesel as fuel for diesel engine, Journal of Engineering and Applied Science Volume 4, pg 8-18

16. Pulkrabek, W.W., (1997) Engineering Fundamentals of the Internal Combustion Engine, Prentice Hall, New Jersey,

17. Schumacher LG, Hires WG and Borgelt SC (1992). Fuelling Diesel Engines with Methyl-Ester Soybean Oil, Liquid Fuels From Renewable Resources. Proceedings of Alternative Energy Conference, Nashville.

18. Sen, A.K, Longwic R, Litak, G and Górski, K. (2008),Cycle-to-cycle pressure oscillations in diesel, Mechanical Systems and Signal Processing vol. 22 pg 362-373

19. Stone, R., (1994). Introduction to Internal Combustion Engines, Macmillan, London.

20. Vivek K.G, Prerana N and Shubhankar B (2012), Combustion Modeling of Diesel Engine Using Bio-Diesel as Secondary Fuel. International Conference on Mechanical and Robotics Engineering (ICMRE'2012) May 26-27, 2012 Phuket 
APPENDICES

Table 1 Result of the Absolute Pressure

Processes

Diesel Biodiesel

Intake $P_{a}, M P a$

0.147

0.153

Compression $P_{\mathcal{C}}, M P a$

6.935

7.203

Combustion $P_{z}, M P a$

13.18

13.69

Expansion $P_{b}, M P a$

0.455

0.473

Table 2 Result of the Absolute Temperature

\begin{tabular}{lcc}
\hline Processes & Diesel & Biodiesel \\
\hline Intake $T_{a}, K$ & 333.82 & 332.42 \\
Compression $T_{c}, K$ & 984.28 & 980.15 \\
Combustion $T_{z}, K$ & 2477.92 & 2467.53 \\
Expansion $T_{z}, K$ & 1291.18 & 1286.40
\end{tabular}

'Table 3 Result of the Specific Volume

\begin{tabular}{lll}
\hline Processes & Diesel $\left(\times \mathbf{1 0}^{-4}\right)$ & Biodiesel $\left(\times \mathbf{1 0}^{-\frac{4}{4}}\right)$ \\
\hline Intake $V_{a}, \mathbf{m}^{3}$ & 6.52 & 6.25 \\
Compression $V_{c}, \mathbf{m}^{3}$ & 0.408 & 0.391 \\
Combustion $V_{z}, \mathbf{m}^{3}$ & 0.432 & 0.414 \\
Expansion $V_{b}, \mathbf{m}^{3}$ & 6.52 & 6.25
\end{tabular}


Advances In Multidisciplinary

APis \& Scientific Research

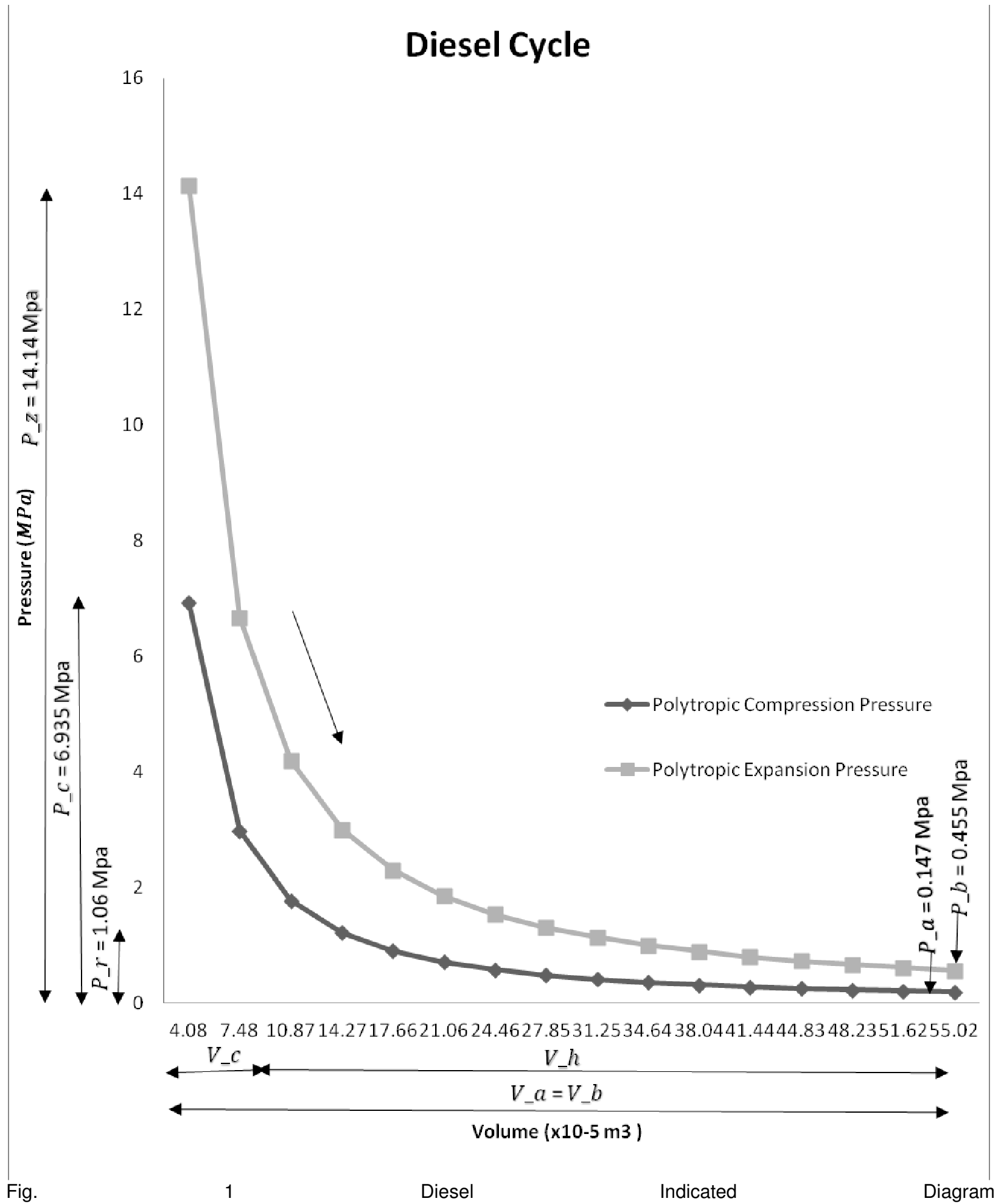


Advances In Multidisciplinary

A 20 \& \& Scientific Research

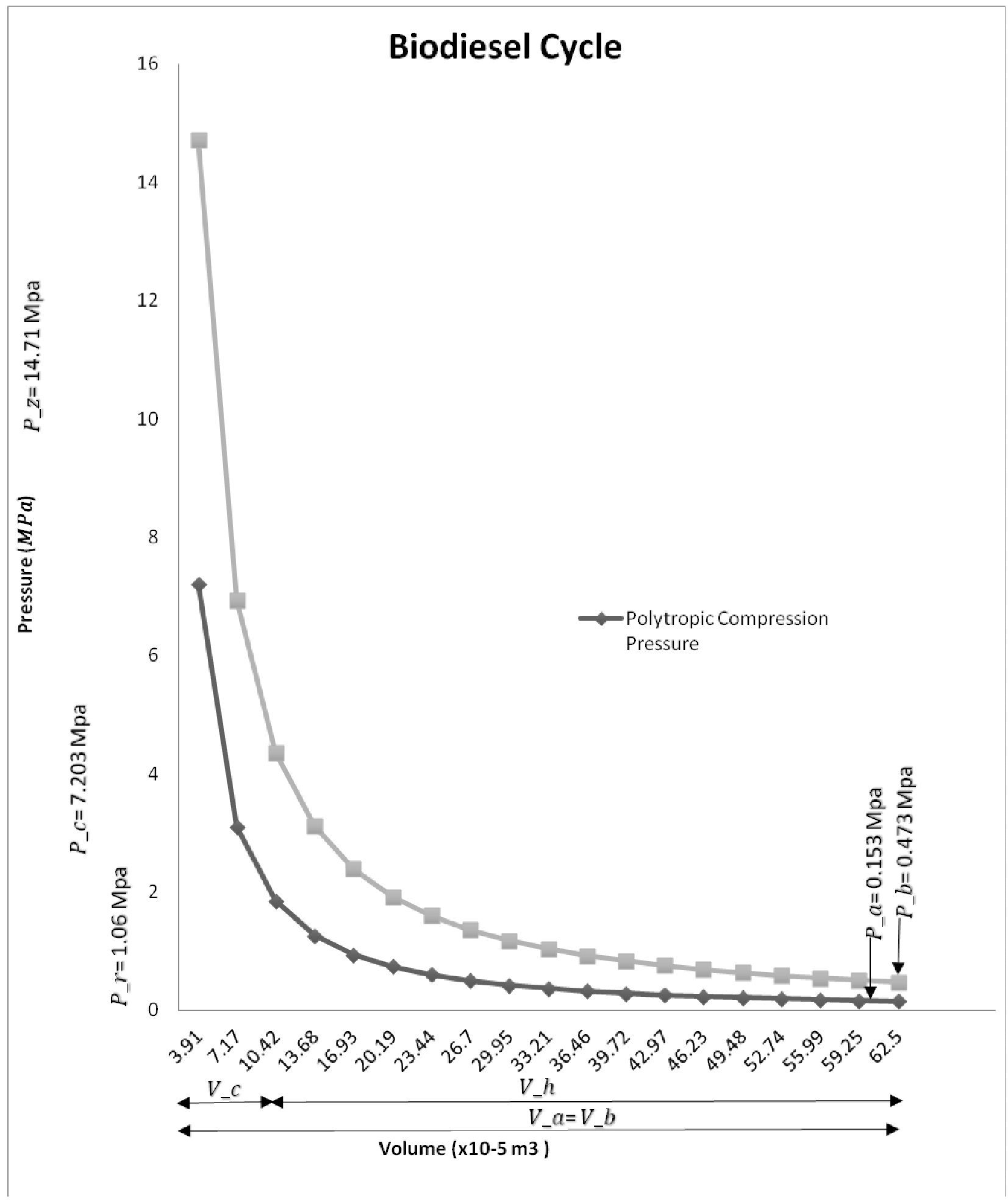




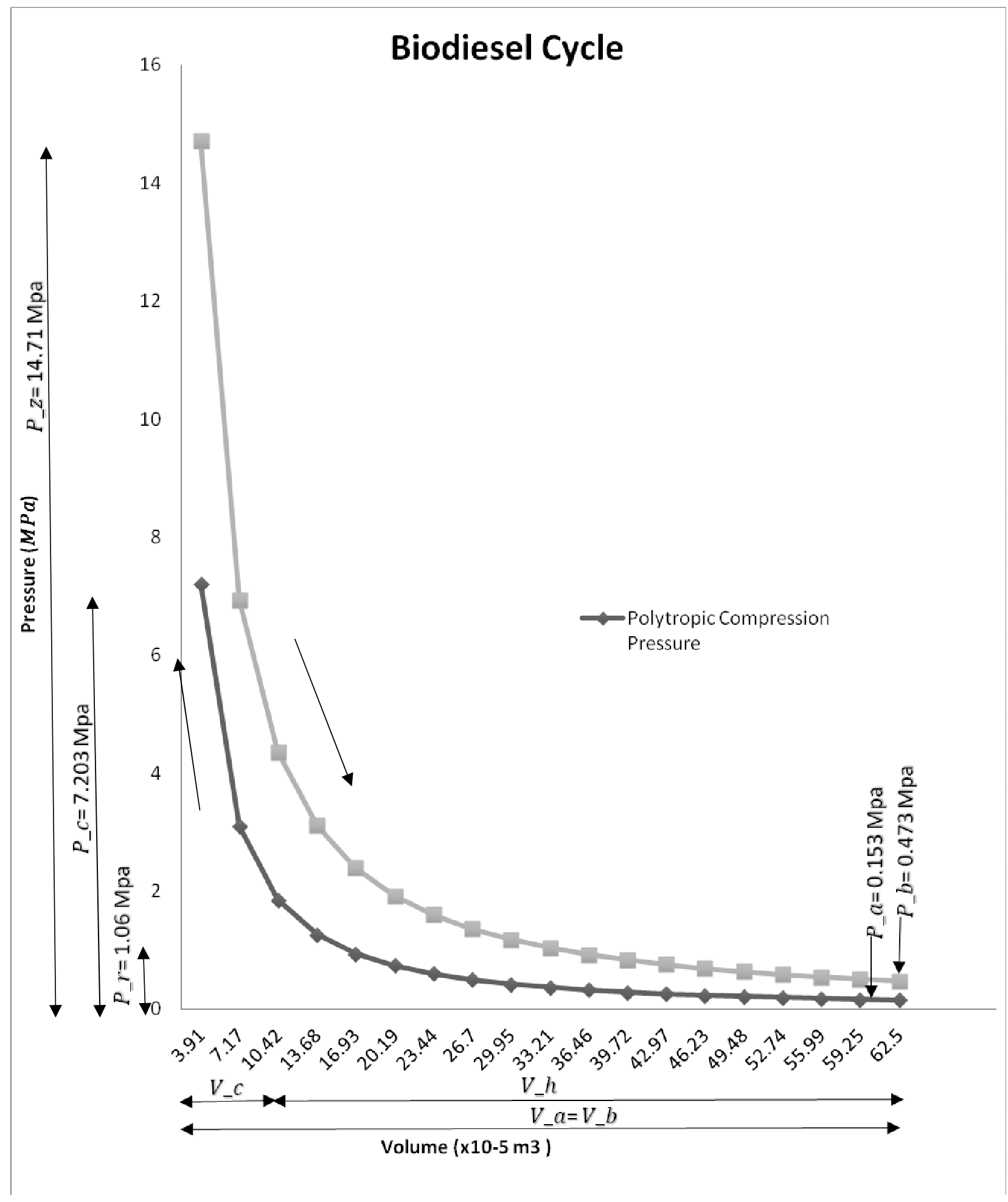

Fig. 2 Biodiesel Indicated Diagram 
Table A1: Results of and used in the construction of Indicated Diagram for diesel Volume $(\mathrm{Vx}) \times 10-5 \mathrm{~m} 3$

(m3)

Compression Pressure ( ) ( )

Expansion Pressure ( ) ( )

\begin{tabular}{lll}
4.08 & 6.923 & 14.14 \\
7.48 & 2.981 & 6.669 \\
10.87 & 1.773 & 4.195 \\
14.27 & 1.215 & 2.994 \\
17.66 & 0.903 & 2.298 \\
21.06 & 0.707 & 1.848 \\
24.46 & 0.574 & 1.535 \\
27.85 & 0.480 & 1.306 \\
31.25 & 0.409 & 1.133 \\
34.64 & 0.354 & 0.997 \\
38.04 & 0.311 & 0.888 \\
41.44 & 0.276 & 0.798 \\
\hline 44.83 & 0.247 & 0.724 \\
\hline 48.23 & 0.224 & 0.661 \\
51.62 & 0.203 & 0.608 \\
55.02 & 0.186 & 0.562 \\
58.42 & 0.171 & 0.521 \\
61.81 & 0.158 & 0.486 \\
65.20 & 0.147 & 0.455
\end{tabular}


Table A2: Results of $V_{x}$ and $P_{x}^{P}$ used in the construction of Indicated Diagram for biodiesel.

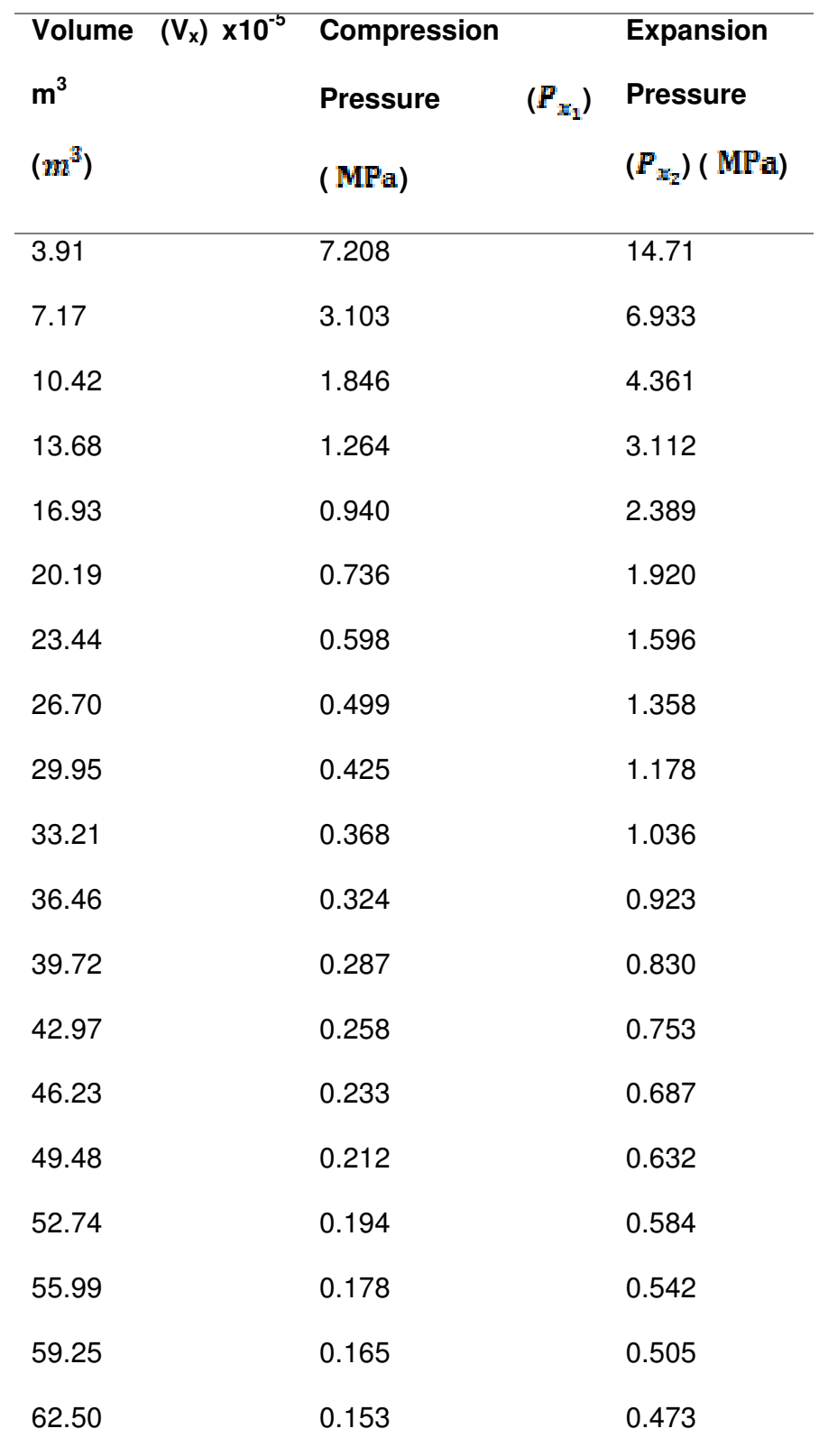

